\title{
Optogenetic Evidence for Inhibitory Signaling from Orexin to MCH Neurons via Local Microcircuits
}

\author{
Di John Apergis-Schoute, ${ }^{1}$ Panagiota Iordanidou, ${ }^{2}$ Cedric Faure, ${ }^{1}$ Sonia Jego, ${ }^{4}$ Cornelia Schöne, ${ }^{2}$ Teemu Aitta-Aho, ${ }^{1}$ \\ Antoine Adamantidis, ${ }^{3,4}$ and Denis Burdakov ${ }^{2,5}$ \\ ${ }^{1}$ Department of Pharmacology, University of Cambridge, Cambridge, CB2 1PD, United Kingdom, ${ }^{2}$ Division of Neurophysiology, MRC National Institute for \\ Medical Research, London NW7 1AA, United Kingdom, ${ }^{3}$ Neurology Department, Bern University Hospital, 3010 Bern, Switzerland, ${ }^{4}$ Department of \\ Psychiatry, McGill University, Montreal, QC H3A 0G4, Canada, and ${ }^{5}$ MRC Centre for Developmental Neurobiology, King's College London, London WC2R \\ 2LS, United Kingdom
}

The lateral hypothalamus ( $\mathrm{LH})$ is a key regulator of multiple vital behaviors. The firing of brain-wide-projecting LH neurons releases neuropeptides promoting wakefulness (orexin/hypocretin; $\mathrm{OH}$ ), or sleep (melanin-concentrating hormone; $\mathrm{MCH}$ ). $\mathrm{OH}$ neurons, which coexpress glutamate and dynorphin, have been proposed to excite their neighbors, including MCH neurons, suggesting that LH may sometimes coengage its antagonistic outputs. However, it remains unclear if, when, and how $\mathrm{OH}$ actions promote temporal separation of the sleep and wake signals, a process that fails in narcolepsy caused by $\mathrm{OH}$ loss. To explore this directly, we paired optogenetic stimulation of $\mathrm{OH}$ cells (at rates that promoted awakening in vivo) with electrical monitoring of MCH cells in mouse brain slices. Membrane potential recordings showed that $\mathrm{OH}$ cell firing inhibited action potential firing in most $\mathrm{MCH}$ neurons, an effect that required $\mathrm{GABA}_{\mathrm{A}}$ but not dynorphin receptors. Membrane current analysis showed that $\mathrm{OH}$ cell firing increased the frequency of fast $\mathrm{GABAergic}$ currents in $\mathrm{MCH}$ cells, an effect blocked by antagonists of $\mathrm{OH}$ but not dynorphin or glutamate receptors, and mimicked by bath-applied $\mathrm{OH}$ peptide. In turn, neural network imaging with a calcium indicator genetically targeted to $\mathrm{MCH}$ neurons showed that excitation by bath-applied $\mathrm{OH}$ peptides occurs in a minority of MCH cells. Collectively, our data provide functional microcircuit evidence that intra-LH feedforward loops may facilitate appropriate switching between sleep and wake signals, potentially preventing sleep disorders.

Key words: GABA; hypocretin; hypothalamus; melanin-concentrating hormone; optogenetics; orexin

\section{Introduction}

The lateral hypothalamus ( $\mathrm{LH})$, historically seen as a vital source of wakefulness signals, is now known to coordinate arousal, sleep, and energy balance (Sakurai, 2002; Saper et al., 2005; de Lecea, 2012; Jego and Adamantidis, 2013). It contains a heterogeneous population of neurons, including those expressing the neuropeptides orexin/hypocretin $(\mathrm{OH})$ or melanin-concentrating hormone $(\mathrm{MCH})$, both of which send wide projections throughout the brain (Bittencourt et al., 1992; Trivedi et al., 1998). In several respects, $\mathrm{OH}$ and $\mathrm{MCH}$ neurons exert antagonistic actions on brain state and energy balance. Deletion of $\mathrm{OH}$ causes inappropriate sleepiness (narcolepsy) and weight gain (Chemelli et al., 1999; Hara et al., 2001), whereas deletion of $\mathrm{MCH}$ or the $\mathrm{MCH}$

Received Dec. 28, 2014; revised Feb. 3, 2015; accepted Feb. 3, 2015.

Author contributions: J.A.-S. and D.B. designed research; J.A.-S., P.I., C.F., S.J., C.S., T.A.-A., and A.A. performed research; A.A. contributed unpublished reagents/analytic tools; J.A.-S., P.I., and D.B. analyzed data; J.A.-S. and D.B. wrote the paper.

This work was supported by the Royal Society Dorothy Hodgkin Fellowship (J.A.-S.) and HFSP Young Investigator Award (RGY0076/2012 to D.B. and A.A.).

The authors declare no competing financial interests.

Correspondence should be addressed to either of the following: Denis Burdakov, MRC Centre for Developmental Neurobiology, King's College London, London WC2R 2LS, UK, E-mail: denis.burdakov@kcl.ac.uk; or Dr John Apergis-Schoute, Department of Pharmacology, University of Cambridge, Cambridge, CB2 1PD, UK. E-mail: ja451@cam.ac.uk.

DOI:10.1523/JNEUROSCI.5269-14.2015

Copyright $\odot 2015$ the authors $\quad 0270-6474 / 15 / 355435-07 \$ 15.00 / 0$ receptor 1 results in increased hyperactivity and leanness (Shimada et al., 1998; Marsh et al., 2002; Takase et al., 2014). OH cell activation produces awakening (Adamantidis et al., 2007), whereas MCH cell activation promotes REM sleep (Jego et al., 2013; Tsunematsu et al., 2014). Chronic activation of MCH cells randomly and independently of sleep state can also increase NREM sleep (Jego and Adamantidis, 2013; Konadhode et al., 2013).

In vivo recordings suggest that $\mathrm{MCH}$ neurons fire during REM sleep, whereas $\mathrm{OH}$ neurons fire during wakefulness (Hassani et al., 2009). However, bath application of $\mathrm{OH}$ peptides can excite $\mathrm{MCH}$ neurons in vitro (van den Pol et al., 2004; Li and van den Pol, 2006). Hypothetically, these apparently contradictory observations could be reconciled if $\mathrm{OH}$ cell activity had a dual effect on the $\mathrm{MCH}$ network. For example, excitation of some MCH cells by $\mathrm{OH}$ may result in coactivation of antagonist signals, which is considered useful for fine control in some systems (Smith, 1981; Baratta et al., 1988; Cui et al., 2013: Tecuapetla et al., 2014). Concurrently, $\mathrm{OH}$-dependent wakefulness would be protected from sleep intrusions if most MCH neurons were inhibited by $\mathrm{OH}$ cell firing, through as yet unidentified circuits. These hypotheses can be directly investigated by recording from $\mathrm{MCH}$ cells during $\mathrm{OH}$ cell firing, and by examining $\mathrm{OH}$ peptide effects at the level of MCH cell network. Recent technological advances allow the latter to be assessed by network-level calcium imaging (Chen 

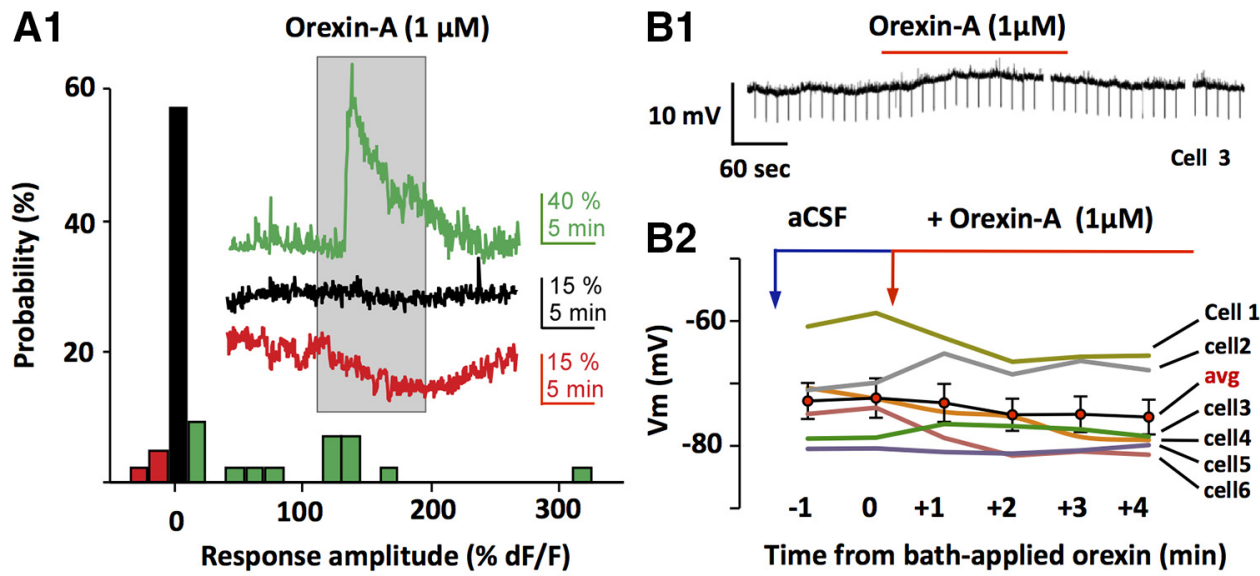

Time from bath-applied orexin $(\mathrm{min})$
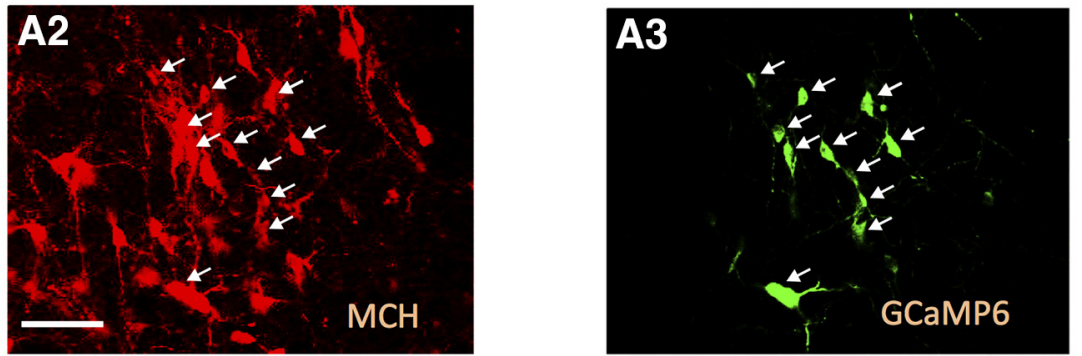

Figure 1. Responses of $\mathrm{MCH}$ neurons to bath-applied orexin peptide. $A$, Summary of intracellular calcium responses of individual $\mathrm{MCH}$ neurons to $1 \mu \mathrm{m}$ bath-applied orexin-A (A1; $n=42$ cells). Traces show examples of excitation (green), inhibition (red), and no response (black). $A 2, A 3$, Confirmation of localization of GCaMP6s calcium indicator to MCH neurons (see Materials and Methods). Scale bar, $80 \mu \mathrm{m}$. B , Effect of bath applied orexin-A on MCH cell membrane potential; typical example (B1) and group data (B2).

et al., 2013), and the former by optogenetics-assisted circuit analysis (Petreanu et al., 2007). Here we apply both of these tools to explore how $\mathrm{OH}$ cell activity influences $\mathrm{MCH}$ neurons.

\section{Materials and Methods}

Gene transfer. Animal procedures followed United Kingdom Home Office regulations. AAV constructs carrying channelrhodopsin-2 (ChR2) and lentiviruses expressing mCherry under the control of $\mathrm{MCH}$ promoter were bilaterally stereotactically coinjected into the LH of orexin-cre mice of either sex (Matsuki et al., 2009; Sasaki et al., 2011). This targets ChR2 expression to OH neurons (Schöne et al., 2012). To target expression of mCherry to $\mathrm{MCH}$ neurons, we used a lentiviral vector carrying the $0.9 \mathrm{~kb}$ preproMCH gene promoter. The specificity of lentivirus-mediated expression was tested by stereotactic delivery of $\mathrm{MCH}:: \mathrm{mCherry}$ lentiviral vector $\left(>10^{9} \mathrm{pfu} / \mathrm{ml}\right)$ into the LH of $\mathrm{MCH}::$ eGFP transgenic mice (Stanley et al., 2010), and confirmed by staining with $\mathrm{MCH}$ antibody (see Fig. 2). The $\mathrm{MCH}$ ::mCherry lentivirus used in this study was generated by Penn Vector Core, University of Pennsylvania (VSVG.HIV.MCH.mCherry(p2428), titer $3.16 \times 10^{11} \mathrm{gc} /$ $\mathrm{ml}$. AAV vectors delivering ChR2 were also produced by the Penn Vector Core; we used AAV2-EF1a-DIO-ChR2(E123T/T159C)-eYFP or AAV1.EF1a.DIO.hChR2(H134R)-eYFP.WPRE.hGH. The titers of ChR2-AAVs were $>1.4 \times 10^{13} \mathrm{gc} / \mathrm{ml}$. Three $100 \mathrm{nl}$ injections of the mixed viruses were made at: -1.3 to $-1.4 \mathrm{~mm}$ from bregma; $\pm 0.9 \mathrm{~mm}$ from midline; and $-5.30,-5.15$, and $-5.00 \mathrm{~mm}$ from skull surface. For calcium imaging, AAV carrying cre-dependent GCaMP6s (rAAV9.CAG.Flex.GCaMP6s.WPRE.SV40; Penn Vector Core, lot CS0419, titer $\left.2.74 \times 10^{13} \mathrm{gc} / \mathrm{ml}\right)$ was bilaterally stereotaxically injected into LH of MCH-cre mice (Kong et al., 2010). Three $50 \mathrm{nl}$ injections of the GCaMP6s virus were at: $-1.35 \mathrm{~mm}$ from bregma; $\pm 0.9 \mathrm{~mm}$ from midline; and $-5.30,-5.20$, and $-5.10 \mathrm{~mm}$ from brain surface. To confirm the selectivity of the $\mathrm{Tg}(\mathrm{Pmch}-\mathrm{Cre})$ transgenic mice, animals were crossed with cre-dependent TdTomato reporter (Rosa-CAG-LSLtdTomato-WPRE, line Ai9, Jackson Laboratories) and immunostained for $\mathrm{MCH}$. $85.87 \pm 1.41 \%$ of $\mathrm{MCH}$-immunopositive cells were found to express TdTomato, whereas $99.81 \pm 0.09 \%$ of TdTomato cells expressed
MCH (2432 cells, $n=3$ mice). GCaMP6s fluorescence was not seen after the AAV coding for GCaMP6s was injected into the LH of wild-type mice ( $n=3$ mice), confirming that it was selective to cre-containing neurons.

Calcium imaging, electrophysiology, and photostimulation. Four to six weeks after stereotactic injections, acute brain slices were prepared as in our previous work (Schöne et al., 2012). Mice were maintained on a standard $12 \mathrm{~h}$ light/dark cycle, and slice recordings performed in both the light (11:00 A.M. to 6:00 P.M.) and dark (6:00 P.M. to 9:00 P.M.) parts of the cycle, with similar results. For calcium imaging, brain slices were placed in a recording chamber of an upright microscope (BX61WI, Olympus) controlled by the Olympus Fluoview software (FV10-ASW ver 4.0 ), and perfused at $35^{\circ} \mathrm{C}$ with ACSF. Confocal imaging was performed at $4 \mathrm{~Hz}$ frame-rate through an Olympus $20 \times 0.50 \mathrm{NA}$ objective, with a $488 \mathrm{~nm}$ Argon laser excitation, and 500-545 nm spectral detector emission collection. Movies were motion-corrected (StackReg plugin, ImageJ). A region of-interest (ROI) around each GCaMP6s-positive cell body was selected using the ROI manager in ImageJ. The ROI locations were used to extract the mean fluorescence value for each object on each frame $F(t)$. To correct for background activity and normalize for the fluorescence value of each cell, we first separated experimental trials into two parts: a baseline period corresponding to all the frames recorded before one frame after the presentation of orexin, and a stimulus period, beginning $4 \mathrm{~s}$ after the onset of orexin application and lasting $10 \mathrm{~min}$. Next, for each ROI we calculated $\% d F / F$ for each frame $(t)$, where $d F / F=(F(t)-F){ }^{\star} 100 / F$, and $F$ was the mean fluorescence value for that ROI for all frames in the baseline period for that trial. For whole-cell patch-clamp recordings, performed and analyzed as in our previous work (Schöne et al., 2012), MCH cells were visualized in acute living brain slices using a mCherry filter set (Chroma). To stimulate ChR2, we used a Thorlabs blue LED, delivering $\sim 10 \mathrm{~mW} / \mathrm{mm}^{2}$ light to ChR2-containing axons around the recorded cell through a $40 \times 0.8 \mathrm{NA}$ objective. Whole-cell recordings were performed at $37^{\circ} \mathrm{C}$ using an EPC-10 amplifier and Patch-Master software (HEKA Elektronik). Averaged data are presented as the mean \pm SEM. Statistical significance was evaluated using ANOVA with Bonferonni post-test, unless stated otherwise.

Chemicals and solutions. Slice-cutting and recording ACSF was gassed with $95 \% \mathrm{O}_{2}$ and $5 \% \mathrm{CO}_{2}$, and contained the following (mM): $125 \mathrm{NaCl}$, 

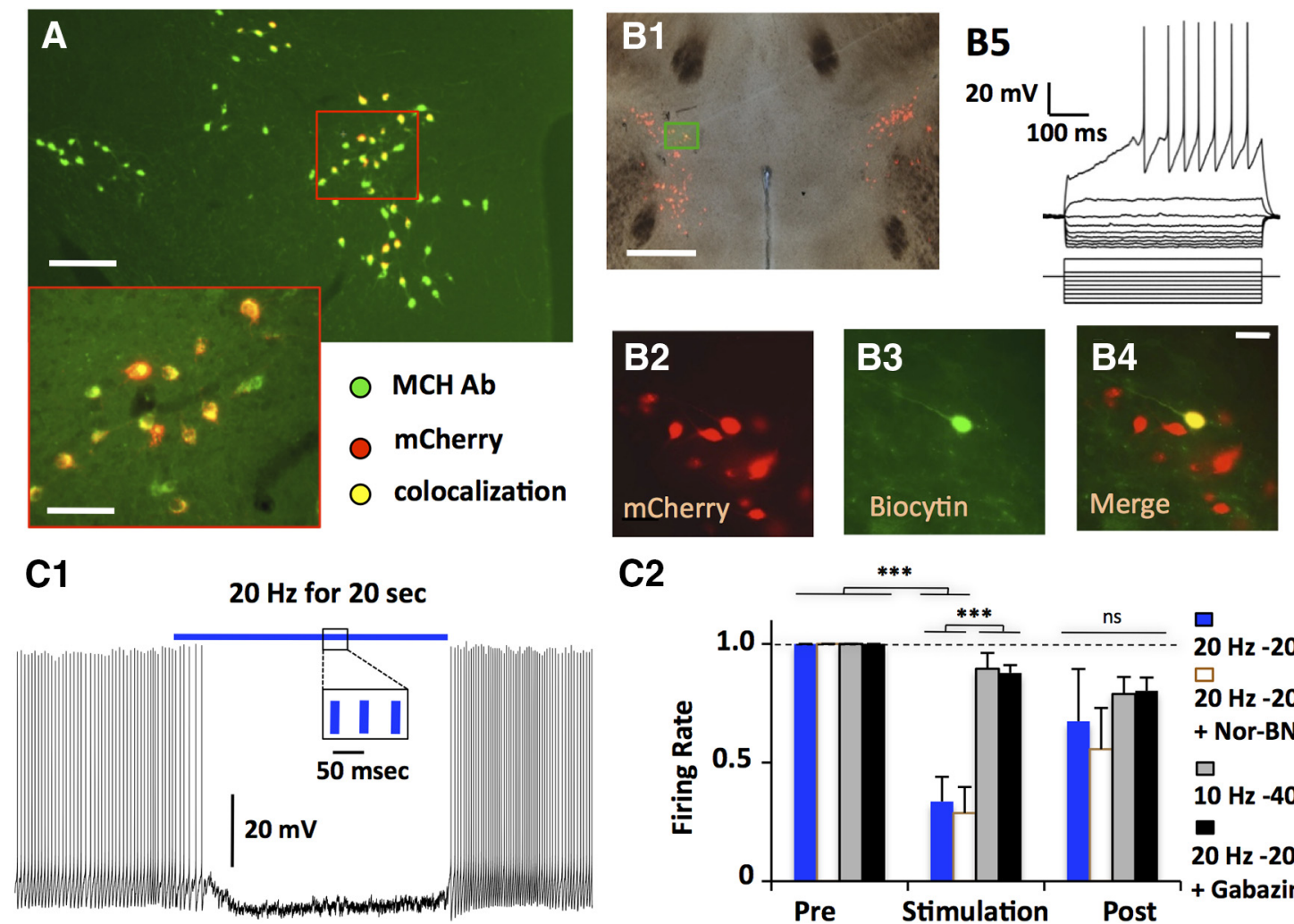

C2

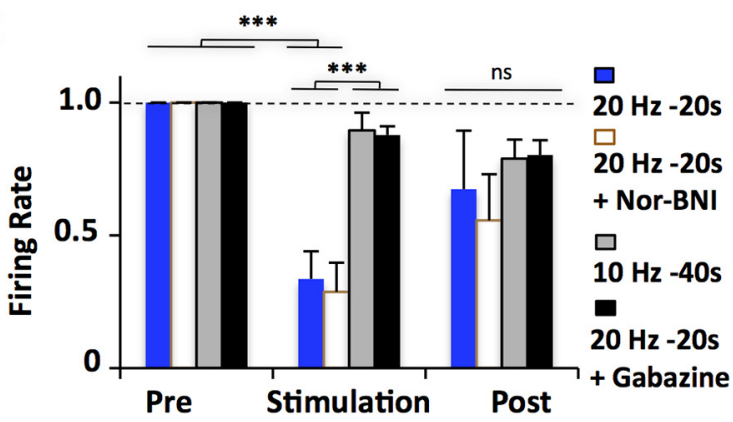

Figure 2. Membrane potential effects in MCH neurons of activation of intrinsic $\mathrm{OH}$ neurons. $A$, Targeted expression of mCherry in MCH neurons ( $n=3$ animals, $630 / 638 \mathrm{mCherry} \mathrm{cells} \mathrm{colocalised}$ with MCH). Scale bars: top, $200 \mu \mathrm{m}$; inset, $40 \mu \mathrm{m}$. B. Whole-cell recordings in mCherry-expressing neurons (B2) were confirmed by filling neurons with biocytin (B3, B4). Membrane potential responses to current injections $(\boldsymbol{B} 5) ; n=50$ cells. $C$, Effect of optogenetic stimulation of $\mathrm{OH}$ neurons. Typical example $(\mathbf{C} \mathbf{1})$ and summary of effects of different stimulation frequencies and drug conditions on firing rate, normalized to prestimulation firing $(C 2) ; n=7$ cells, two-way ANOVA, $F_{(2,42)}=21.37$, Bonferroni post-test; ${ }^{* * *} p<0.001 ;$ ns, nonsignificant $(p>0.05)$.

$25 \mathrm{NaHCO}_{3}, 3 \mathrm{KCl}, 1.25 \mathrm{NaH}_{2} \mathrm{PO}_{4}, 1 / 2 \mathrm{CaCl}_{2}$ (cutting/recording), 6/1 $\mathrm{MgCl}_{2}$ (cutting/recording), 3 sodium pyruvate, and 25/5 glucose (cutting/recording). Pipettes were filled with (in $\mathrm{mm}$ ): 135 potassium gluconate, $7 \mathrm{NaCl}$, 10 HEPES, $2 \mathrm{Na}_{2}$-ATP, $0.3 \mathrm{Na}-\mathrm{GTP}$, and $2 \mathrm{MgCl}_{2}$; $\mathrm{pH}$ was adjusted to 7.3 with $\mathrm{KOH}$. Drug concentrations were (in $\mu \mathrm{m}$ ): 20 CNQX and 100 AP5, 10 gabazine, 1 TTX, 5 nor-binaltorphimine dihydrochloride (nor-BNI), 10 SB-334867 (SB), and 10 TCS-OX2-29 (TCS). All chemicals were from Signal, Tocris Bioscience, or Bachem.

Immunocytochemistry. Primary antibodies were as follows: goat antiorx-B (1:1000; Santa Cruz Biotechnology), rabbit anti-GABA (1:500; Immunostar), and rabbit anti-MCH (1:1000, Phoenix Pharmaceuticals) Secondary antibodies were AlexaFluor 594 donkey anti-rabbit and AlexaFluor 488 donkey anti-goat (both 1:1000; Thermo Fisher). Orexin, $\mathrm{MCH}$, and biocytin immunostaining was performed as in our previous work (Burdakov et al., 2005). For GABA immunostaining, tissue was heated to $80^{\circ} \mathrm{C}$ for $30 \mathrm{~min}$ in sodium citrate ( $\mathrm{pH} \mathrm{8}$; Sigma-Aldrich), washed in $0.1 \mathrm{M}$ PBS, treated three times for $5 \mathrm{~min}$ in sodium borohydride solution $(1 \mathrm{mg} / \mathrm{ml}$ in PBS), again washed in $0.1 \mathrm{M}$ PBS, and blocked/ permeabilized in PBS with 0.3\% Triton X-100 (Sigma-Aldrich) and 5\% donkey serum (Sigma-Aldrich). Sections were then incubated overnight in blocking solution with rabbit anti-GABA and goat anti-orx-B. On Day 2 , tissue was washed in $0.1 \mathrm{M}$ PBS, incubated in secondary antibodies for $2 \mathrm{~h}$, washed in PBS, and mounted on microscope slides and coverslipped. Digital images were captured with a Zeiss Axioskop 2 microscope and QImaging QICAM Fast digital camera. Images were merged using ImageJ (National Institutes of Health). Expression was analyzed separately and subsequently merged and counted manually.

\section{Results}

Artificially applied orexin/hypocretin excites a minor part of the $\mathrm{MCH}$ network

To explore $\mathrm{OH}$ peptide effects on $\mathrm{MCH}$ network, we first targeted genetically encoded calcium indicators selectively to $\mathrm{MCH}$ neu- rons in MCH-cre transgenic mice (see Materials and Methods; Fig. 1A). This allows monitoring of neuronal excitation by using cytosolic calcium concentration as a proxy (Chen et al., 2013). In this assay, $\sim 30 \%$ of MCH neurons were activated by $1 \mu \mathrm{M}$ bathapplied orexin-A; the rest were either unaffected or inhibited (Fig. 1A). Second, we performed whole-cell current-clamp recordings, where bath application of $1 \mu \mathrm{M}$ orexin-A also had mixed effects on $\mathrm{MCH}$ cell membrane potential: some $\mathrm{MCH}$ neurons slightly depolarized, but others were hyperpolarized or did not respond (2/6 and 4/6 cells, respectively; Fig. $1 B$ ). These results are consistent with previous work showing that some $\mathrm{MCH}$ neurons can be activated by $1 \mu \mathrm{M}$ artificially applied orexin (van den Pol et al., 2004; Li and van den Pol, 2006), but our data suggest that this activation occurs in a minority of $\mathrm{MCH}$ cells.

\section{Firing of $\mathrm{OH}$ neurons exerts inhibitory effects on $\mathrm{MCH}$ cell membrane potential}

Artificial application of neurotransmitters involves arbitrarily chosen concentrations that may not correspond to those in native neural networks, potentially creating unnatural responses (e.g., due to receptor desensitization). To examine intrinsic signals generated by $\mathrm{OH}$ cell firing in $\mathrm{MCH}$ neurons, we performed optogenetic analysis of functional connectivity in LH brain slices. To selectively stimulate $\mathrm{OH}$ cells while recording from identified $\mathrm{MCH}$ cells, we expressed light-activated excitatory ion channel $\mathrm{ChR} 2$ in $\mathrm{OH}$ neurons and simultaneously transduced $\mathrm{MCH}$ neurons using lentiviral vector expressing the mCherry fluorescent protein driven by an $\mathrm{MCH}$ gene promoter (Fig. $2 \mathrm{~A}$; see Materials and Methods). Following stereotaxic injections of the mCherry$\mathrm{MCH}$ lentiviruses into the $\mathrm{LH}, \mathrm{mCherry}$-labeled neurons were 

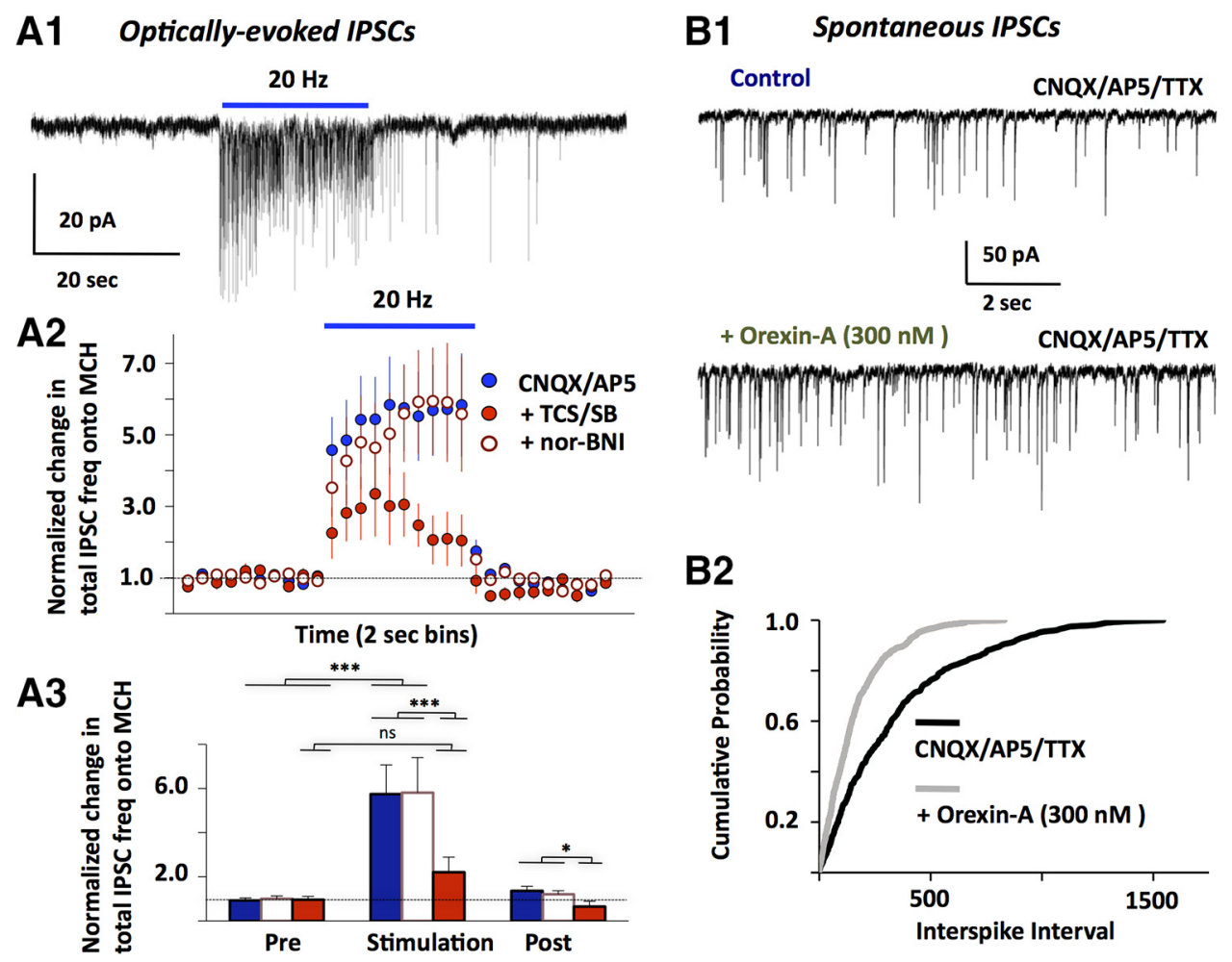

Figure 3. Membrane current effects in $\mathrm{MCH}$ neurons of activating intrinsic $\mathrm{OH}$ neurons, and of bath-applied $\mathrm{OH}$ peptide. $\mathrm{A1}$, Typical example of MCH cell IPSCs caused by optical stimulation of $\mathrm{OH}$ cells ( $n=26$ cells). IPSCs were recorded in the presence of CNQX/AP5, and confirmed as GABAergic by blockade with gabazine. A2, Summary of effects of OH cell stimulation on MCH cell IPSC tone, under different drug conditions ( $n=26$ cells). A3, Comparison of IPSC tone at different times relative to the optical stimulation ( $6 \mathrm{~s}$ before, last $6 \mathrm{~s}$ of stimulation, and $6 \mathrm{~s}$ after the stimulation). Color codes and data are the same as in A2. Two-way ANOVA, $F_{(2,42)}=21.37$, Bonferroni post-test: ${ }^{* * *} p<0.001 ;{ }^{*} p<0.05$; ns, nonsignificant $(p>0.05)$. B1, Typical example of effect of bath applied orexin-A on miniature IPSCs ( $n=5$ cells). B2, Comparison of miniature IPSC frequency with and without bath orexin; $n=5$ cells, Kolmogorov-Smirnov test, $p<0.001$.

found only in the previously reported locations of $\mathrm{MCH}$ neurons (the Zona Incerta, Lateral and Dorsomedial Hypothalamus; Fig. $2 A, B 1)$. MCH-like immunoreactivity was found in $98.7 \%$ of mCherry-labeled cells (Fig. 2A; statistics for data shown in the figures are reported in figure legends). Whole-cell recordings from the mCherry cells (Fig. 2B5) revealed typical membrane potential "signatures" of MCH cells (Burdakov et al., 2005), confirming that $\mathrm{MCH}$ cell function was unperturbed by the viral infection. The firing of most $\mathrm{MCH}$-mCherry cells was rapidly reduced when $\mathrm{OH}-\mathrm{ChR} 2$ cells were optically paced at a frequency that we previously found to cause awakening in vivo $(20 \mathrm{~Hz}$; Adamantidis et al., 2007; Fig. 2C; $n=25 / 32$ cells; note that this represents $\approx 80 \%$ of $\mathrm{MCH}$ cells with only $\approx 40 \%$ of $\mathrm{OH}$ cells transfected with ChR2 in our preparation; Schöne et al., 2012). Lower optical stimulation frequencies were less effective (Fig. 2C2), mirroring stimulation requirement for $\mathrm{OH}$ peptide release in slices (Schöne et al., 2014). Dynorphin is coexpressed in $\mathrm{OH}$ neurons (Muschamp et al., 2014), and extrinsic application of dynorphin can inhibit $\mathrm{MCH}$ neurons via $\kappa$-opiod receptors ( $\mathrm{Li}$ and van den Pol, 2006). However, the $\kappa$-opiod receptor antagonist Nor-BNI did not affect the inhibition of $\mathrm{MCH}$ activity by $\mathrm{OH}$ cell firing (Fig. 2C2). In contrast, the $\mathrm{OH} \rightarrow \mathrm{MCH}$ inhibition was largely abolished by $10 \mu \mathrm{M}$ gabazine, a $\mathrm{GABA}_{\mathrm{A}}$ receptor blocker, suggesting that it is mediated by local GABA release (Fig. 2C2).

\section{$\mathrm{OH}$ cell firing controls GABA input to $\mathrm{MCH}$ cells via $\mathrm{OH}$ receptors}

To further investigate synaptic currents underlying the GABAergic suppression of $\mathrm{MCH}$ cell activity during $\mathrm{OH}$ cell firing, we performed voltage-clamp recordings (at $-80 \mathrm{mV}$ ) in glutamate receptor blockers (CNQX+AP5). Optical stimulation significantly increased the frequency of gabazine-sensitive IPSCs (Fig. $3 A$ ). IPSC frequency increased progressively during optical stimulation (Fig. 3A2), similar to actions of $\mathrm{OH}$ peptides expected to be released by this stimulation (Schöne et al., 2014). Application of $\mathrm{OH}$ receptor antagonists substantially reduced the ability of the optical stimulation to increase GABAergic tone (Fig. 3A). In contrast, $\kappa$-opiod receptor antagonist did not affect the IPSC stimulation (Fig. 3A2,3). If our optical stimulation increases GABA input to $\mathrm{MCH}$ cells by releasing endogenous $\mathrm{OH}$ peptides, then the increase in GABAergic tone should be mimicked by artificially applied $\mathrm{OH}$ peptides. Indeed, bath-applied $\mathrm{OH}$ peptide significantly increased the frequency of miniature $\mathrm{GABA}_{\mathrm{A}}$ mediated IPSCs (Fig. 3B).

Interestingly, in some cases we observed $\mathrm{GABA}_{\mathrm{A}}$-mediated IPSCs in MCH neurons that appeared time-locked $(2-10 \mathrm{~ms}$ latency) to the optical flashes stimulating $\mathrm{OH}$ neurons (Fig. $4 A)$. The probability of the short-latency ( $<10 \mathrm{~ms})$ IPSCs was also increased by bath-applied $\mathrm{OH}$ peptide (Fig. 4A3). It has been suggested that latencies $>1.8 \mathrm{~ms}$ may represent indirect, polysynaptic connections (Gil and Amitai, 1996). Thus, our latencies could mean that $\mathrm{OH}$ neurons fire GABA interneurons projecting to $\mathrm{MCH}$ cells, presumably by releasing $\mathrm{OH}$ peptide since the responses persisted in glutamate receptor blockers (Fig. 4A1). Alternatively, due to delays between optical flashes and the spikes they evoke in ChR2-expressing cells (Tecuapetla et al., 2010), it cannot be excluded that some $\mathrm{OH}$ cells may release GABA onto $\mathrm{MCH}$ cells. Indeed, it has been previously hypothesized based on immunocytochemistry, real-time PCR, and electron-microscopy that a subgroup of 


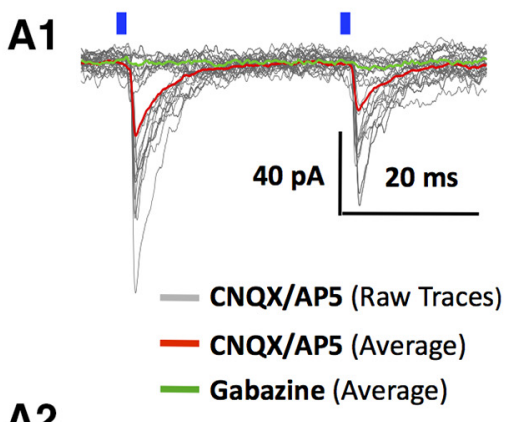

A2
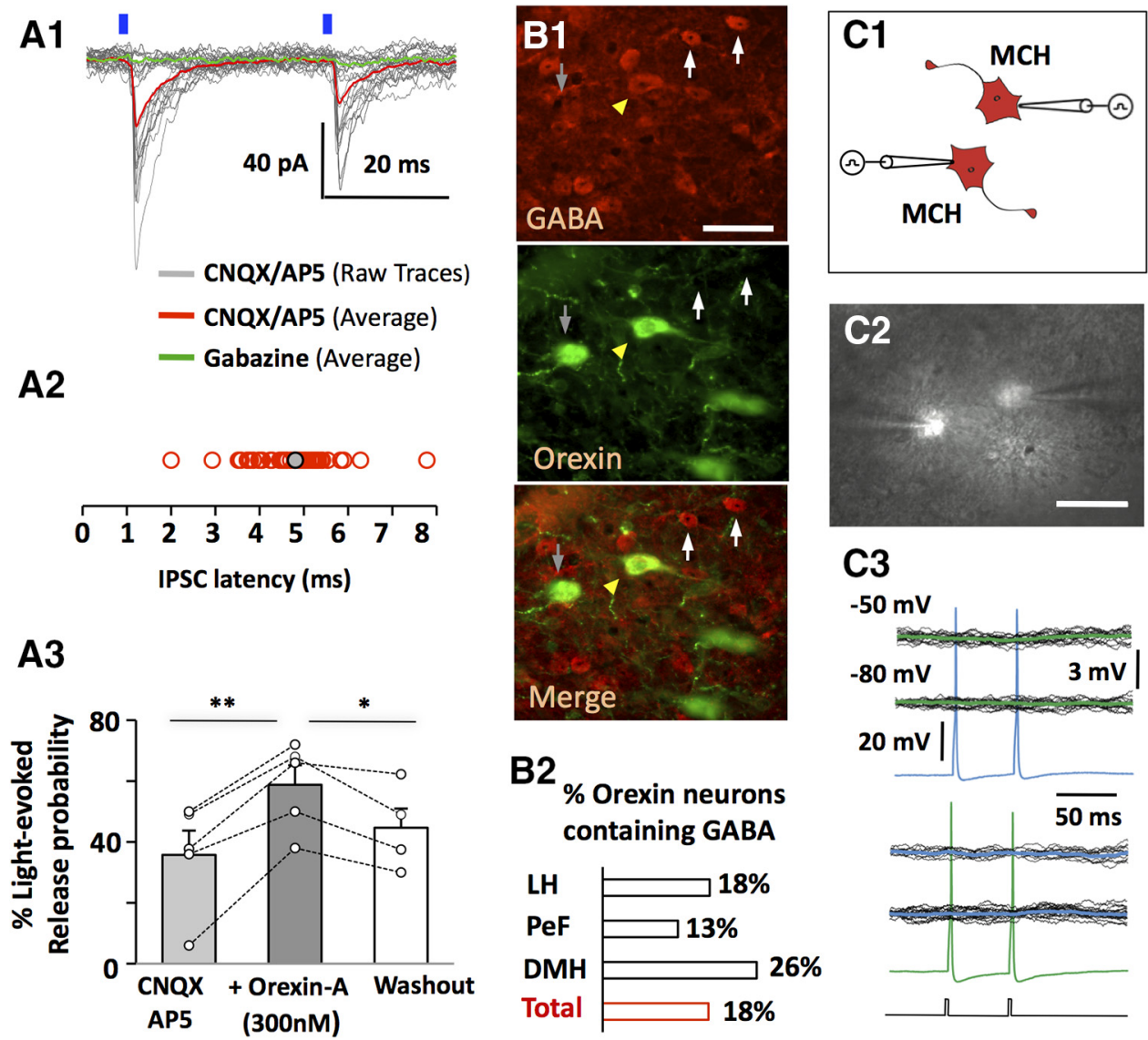

Figure 4. Inhibitory actions and GABA content of $\mathrm{OH}$ neurons. $\boldsymbol{A}$ 1, An example of a short-latency ( $<10 \mathrm{~ms})$ IPSC evoked by a blue laser flashes $(n=7$ cells). $\boldsymbol{A 2}$, distribution of short latencies ( $\boldsymbol{A 2}$; $n=48$ cells). A3, effect on bath-applied orexin-A on short-latency IPSC recorded as in $\boldsymbol{A} \mathbf{1}\left(n=5\right.$ cells). Paired two-tailed Student's $t$ test, ${ }^{* *} p<0.005,{ }^{*} p<0.05 ; n s$, nonsignificant $(p>0.05$ ). $B$, Orexin-containing neurons immunopositive for GABA (B1) are distributed throughout hypothalamic subregions. The number of $0 \mathrm{H}$-immunopositive cells colocalized with GABA were as follows: LH, 107/590; perifornical area (PeF), 23/88; dorsomedial hypothalamus (DMH), 29/226; total 159/908 cells ( $n=3$ brains; B2). Scale bar, $40 \mu$ m. C, Schematic (C1) and live brain-slice image (C2) of paired recordings from MCH-mCherry neurons. Scale bar, $50 \mu \mathrm{m}$. C3, representative recordings from an MCH-MCH cell pair, showing that evoked action potentials in one cell did not produce postsynaptic current in the other. Black lines are individual traces and green/blue are averaged traces. Current-clamp protocol used to evoke action potentials is shown below the traces. Similar results were obtained from 43 cell pairs.

OH cells may release GABA (Guan et al., 2002; Harthoorn et al., 2005; Balcita-Pedicino and Sesack, 2007). We confirmed that GABA-like immunoreactivity is present in a subpopulation of $\mathrm{OH}$ neurons $(10-25 \%$ of $\mathrm{OH}$ cells, depending on $\mathrm{LH}$ area; Fig. $4 B$, but see Discussion).

At least some MCH cells are GABAergic (Jego et al., 2013), and some may be excited by $\mathrm{OH}$ neurons (Fig. 1A1; Guan et al., 2002; van den Pol et al., 2004; Li and van den Pol, 2006). This suggests a possibility that some of $\mathrm{OH}$-dependent GABA drive to $\mathrm{MCH}$ neurons may come from other $\mathrm{MCH}$ neurons. To test this, we performed dual whole-cell recordings from identified $\mathrm{MCH}$ mCherry cell pairs (Fig. 4C). We generated action potentials in one $\mathrm{MCH}$ cell, while recording synaptic responses in another $\mathrm{MCH}$ cell. We did not find evidence of $\mathrm{MCH}$-to-MCH functional connectivity: presynaptic action potentials did not generate detectable postsynaptic responses in $43 \mathrm{MCH}-\mathrm{MCH}$ cell pairs tested (Fig. 4C).

\section{Discussion}

A key question in systems neuroscience is how the brain ensures that opposing signals, such those causing sleep and wake transitions, are scheduled to occur at separate times. Inappropriate co-occurrence of such signals can produce pathological brain states and behaviors, for example concurrent wakefulness and sleep-paralysis (Dauvilliers et al., 2007). Our results provide a network-level explanation for how such pathological mixing of opposing neural drives may be prevented by natural LH microcircuits. Our data suggest that when $\mathrm{OH}$ neurons fire at rates that promote awakening (Adamantidis et al., 2007), the spike output of most MCH neurons is suppressed, due to increased GABAergic drive into those cells (Fig. 2C). The GABAergic inhibition of $\mathrm{MCH}$ cells depends significantly on $\mathrm{OH}$ receptors, whereas glutamate receptors are not essential (Fig. 3A2). This is consistent with our previous data that $\mathrm{OH}$ (but not glutamate) transmission is critical for translating $\mathrm{OH}$ cell firing into sustained postsynaptic electrical responses (Schöne et al., 2014). Our data are also consistent with the possibility that $\mathrm{OH}$ may release GABA themselves (Fig. 4). However, further molecular and ultra-structural data would be necessary to ascertain how $\mathrm{OH}$ cells may produce GABA and/or package it into vesicles, because the GABA staining we observed may be cytosolic (and not vesicular), and we found no evidence of $\mathrm{OH}$ immunoreactivity in vgat-positive neurons of the LH (D. Burdakov and J. Apergis-Schoute, unpublished observations). It remains to be determined whether $\mathrm{OH}$ neurons may acquire GABAergic functional identity through noncanonical transporters, such as recently reported for dopamine neurons (Tritsch et al., 2012, 2014). 
More broadly, our results offer a reconciliation for the apparent contradictions in existing in vitro and in vivo data on relative timing of $\mathrm{OH}$ and $\mathrm{MCH}$ cell activity (van den Pol et al., 2004; Hassani et al., 2009). Although we observed only inhibitory effects during intrinsic $\mathrm{OH}$ cell $\rightarrow \mathrm{MCH}$ cell actions (consistent with Hassani et al., 2009), our data with bath applications of $\mathrm{OH}$ peptide suggested that it may also directly excite some $\mathrm{MCH}$ neurons (consistent with van den Pol et al., 2004). It is possible that the high levels of $\mathrm{OH}$ peptide required to excite $\mathrm{MCH}$ cells are not attained during optogenetic stimulation in slices or during acute experiments. In vivo, during overexcitation of $\mathrm{OH}$ cells, it remains possible that $\mathrm{OH}$ peptides may reach high-enough levels to excite $\mathrm{MCH}$ cells directly, which may provide a feedback mechanism preventing hyperarousal. In terms of natural drives of $\mathrm{OH}$ neurons, there is evidence that noradrenaline input to $\mathrm{OH}$ cells may switch sign after sleep deprivation due to a switch in receptor type (Grivel et al., 2005; Uschakov et al., 2011). This suggests the coupling of $\mathrm{MCH}$ cell activity to arousal state in general, and to noradrenaline drive in particular, may change as a function of stress or sleep pressure, an interesting possibility that deserves future investigation.

We predict that the $\mathrm{OH}$ receptor-dependent intrinsic $\mathrm{OH} \rightarrow$ $\mathrm{MCH}$ inhibitory signaling (Fig. 3A2) is mediated by local $\mathrm{OH}-$ excited GABA neurons. It would be important to determine the identities of these neurons in future investigations, and our paired recordings (Fig. 4C) currently suggest that these GABA cells may be separate from $\mathrm{MCH}$ neurons themselves. At the level of local circuits in the $\mathrm{LH}$, our data provide functional experimental support for the "flip-flop" model of binary switching between sleep and wake signals (Saper et al., 2005). The GABAergic microcircuits mediating $\mathrm{OH} \rightarrow \mathrm{MCH}$ cell inhibition may constitute a new therapeutic target, because they are likely to oppose the pathological mixing of sleep and wake states in disorders such as narcopelsy.

\section{References}

Adamantidis AR, Zhang F, Aravanis AM, Deisseroth K, de Lecea L (2007) Neural substrates of awakening probed with optogenetic control of hypocretin neurons. Nature 450:420-424. CrossRef Medline

Balcita-Pedicino JJ, Sesack SR (2007) Orexin axons in the rat ventral tegmental area synapse infrequently onto dopamine and gamma-aminobutyric acid neurons. J Comp Neurol 503:668-684. CrossRef Medline

Baratta R, Solomonow M, Zhou BH, Letson D, Chuinard R, D'Ambrosia R (1988) Muscular coactivation: the role of the antagonist musculature in maintaining knee stability. Am J Sports Med 16:113-122. CrossRef Medline

Bittencourt JC, Presse F, Arias C, Peto C, Vaughan J, Nahon JL, Vale W, Sawchenko PE (1992) The melanin-concentrating hormone system of the rat brain: an immuno- and hybridization histochemical characterization. J Comp Neurol 319:218-245. CrossRef Medline

Burdakov D, Gerasimenko O, Verkhratsky A (2005) Physiological changes in glucose differentially modulate the excitability of hypothalamic melanin-concentrating hormone and orexin neurons in situ. J Neurosci 25:2429-2433. CrossRef Medline

Chemelli RM, Willie JT, Sinton CM, Elmquist JK, Scammell T, Lee C, Richardson JA, Williams SC, Xiong Y, Kisanuki Y, Fitch TE, Nakazato M, Hammer RE, Saper CB, Yanagisawa M (1999) Narcolepsy in orexin knockout mice: molecular genetics of sleep regulation. Cell 98:437-451. CrossRef Medline

Chen TW, Wardill TJ, Sun Y, Pulver SR, Renninger SL, Baohan A, Schreiter ER, Kerr RA, Orger MB, Jayaraman V, Looger LL, Svoboda K, Kim DS (2013) Ultrasensitive fluorescent proteins for imaging neuronal activity. Nature 499:295-300. CrossRef Medline

Cui G, Jun SB, Jin X, Pham MD, Vogel SS, Lovinger DM, Costa RM (2013) Concurrent activation of striatal direct and indirect pathways during action initiation. Nature 494:238-242. CrossRef Medline

Dauvilliers Y, Arnulf I, Mignot E (2007) Narcolepsy with cataplexy. Lancet 369:499-511. CrossRef Medline de Lecea L (2012) Hypocretins and the neurobiology of sleep-wake mechanisms. Prog Brain Res 198:15-24. CrossRef Medline

Gil Z, Amitai Y (1996) Properties of convergent thalamocortical and intracortical synaptic potentials in single neurons of neocortex. J Neurosci 16:6567-6578. Medline

Grivel J, Cvetkovic V, Bayer L, Machard D, Tobler I, Mühlethaler M, Serafin M (2005) The wake-promoting hypocretin/orexin neurons change their response to noradrenaline after sleep deprivation. J Neurosci 25:41274130. CrossRef Medline

Guan JL, Uehara K, Lu S, Wang QP, Funahashi H, Sakurai T, Yanagizawa M, Shioda S (2002) Reciprocal synaptic relationships between orexin- and melanin-concentrating hormone-containing neurons in the rat lateral hypothalamus: a novel circuit implicated in feeding regulation. Int J Obes Relat Metab Disord 26:1523-1532. CrossRef Medline

Hara J, Beuckmann CT, Nambu T, Willie JT, Chemelli RM, Sinton CM, Sugiyama F, Yagami K, Goto K, Yanagisawa M, Sakurai T (2001) Genetic ablation of orexin neurons in mice results in narcolepsy, hypophagia, and obesity. Neuron 30:345-354. CrossRef Medline

Harthoorn LF, Sañé A, Nethe M, Van Heerikhuize JJ (2005) Multitranscriptional profiling of melanin-concentrating hormone and orexincontaining neurons. Cell Mol Neurobiol 25:1209-1223. CrossRef Medline

Hassani OK, Lee MG, Jones BE (2009) Melanin-concentrating hormone neurons discharge in a reciprocal manner to orexin neurons across the sleep-wake cycle. Proc Natl Acad Sci U S A 106:2418-2422. CrossRef Medline

Jego S, Adamantidis A (2013) MCH neurons: vigilant workers in the night. Sleep 36:1783-1786. CrossRef Medline

Jego S, Glasgow SD, Herrera CG, Ekstrand M, Reed SJ, Boyce R, Friedman J, Burdakov D, Adamantidis AR (2013) Optogenetic identification of a rapid eye movement sleep modulatory circuit in the hypothalamus. Nat Neurosci 16:1637-1643. CrossRef Medline

Konadhode RR, Pelluru D, Blanco-Centurion C, Zayachkivsky A, Liu M, Uhde T, Glen WB Jr, van den Pol AN, Mulholland PJ, Shiromani PJ (2013) Optogenetic stimulation of MCH neurons increases sleep. J Neurosci 33:10257-10263. CrossRef Medline

Kong D, Vong L, Parton LE, Ye C, Tong Q, Hu X, Choi B, Brüning JC, Lowell BB (2010) Glucose stimulation of hypothalamic MCH neurons involves $\mathrm{K}(\mathrm{ATP})$ channels, is modulated by UCP2, and regulates peripheral glucose homeostasis. Cell Metab 12:545-552. CrossRef Medline

Li Y, van den Pol AN (2006) Differential target-dependent actions of coexpressed inhibitory dynorphin and excitatory hypocretin/orexin neuropeptides. J Neurosci 26:13037-13047. CrossRef Medline

Marsh DJ, Weingarth DT, Novi DE, Chen HY, Trumbauer ME, Chen AS, Guan XM, Jiang MM, Feng Y, Camacho RE, Shen Z, Frazier EG, Yu H, Metzger JM, Kuca SJ, Shearman LP, Gopal-Truter S, MacNeil DJ, Strack AM, MacIntyre DE, et al. (2002) Melanin-concentrating hormone 1 receptor-deficient mice are lean, hyperactive, and hyperphagic and have altered metabolism. Proc Natl Acad Sci U S A 99:3240-3245. CrossRef Medline

Matsuki T, Nomiyama M, Takahira H, Hirashima N, Kunita S, Takahashi S, Yagami K, Kilduff TS, Bettler B, Yanagisawa M, Sakurai T (2009) Selective loss of $\mathrm{GABA}(\mathrm{B})$ receptors in orexin-producing neurons results in disrupted sleep/wakefulness architecture. Proc Natl Acad Sci U S A 106: 4459-4464. CrossRef Medline

Muschamp JW, Hollander JA, Thompson JL, Voren G, Hassinger LC, Onvani S, Kamenecka TM, Borgland SL, Kenny PJ, Carlezon WA Jr (2014) Hypocretin (orexin) facilitates reward by attenuating the antireward effects of its cotransmitter dynorphin in ventral tegmental area. Proc Natl Acad Sci U S A 111:E1648-E1655. CrossRef Medline

Petreanu L, Huber D, Sobczyk A, Svoboda K (2007) Channelrhodopsin-2assisted circuit mapping of long-range callosal projections. Nat Neurosci 10:663-668. CrossRef Medline

Sakurai T (2002) Role of orexins in the regulation of feeding and arousal. Sleep Med 3:S3-S9. CrossRef Medline

Saper CB, Scammell TE, Lu J (2005) Hypothalamic regulation of sleep and circadian rhythms. Nature 437:1257-1263. CrossRef Medline

Sasaki K, Suzuki M, Mieda M, Tsujino N, Roth B, Sakurai T (2011) Pharmacogenetic modulation of orexin neurons alters sleep/wakefulness states in mice. PLoS One 6:e20360. CrossRef Medline

Schöne C, Cao ZF, Apergis-Schoute J, Adamantidis A, Sakurai T, Burdakov D (2012) Optogenetic probing of fast glutamatergic transmission from 
hypocretin/orexin to histamine neurons in situ. J Neurosci 32:1243712443. CrossRef Medline

Schöne C, Apergis-Schoute J, Sakurai T, Adamantidis A, Burdakov D (2014) Coreleased orexin and glutamate evoke nonredundant spike outputs and computations in histamine neurons. Cell Rep 7:697-704. CrossRef Medline

Shimada M, Tritos NA, Lowell BB, Flier JS, Maratos-Flier E (1998) Mice lacking melanin-concentrating hormone are hypophagic and lean. Nature 396:670-674. CrossRef Medline

Smith AM (1981) The coactivation of antagonist muscles. Can J Physiol Pharmacol 59:733-747. CrossRef Medline

Stanley S, Pinto S, Segal J, Pérez CA, Viale A, DeFalco J, Cai X, Heisler LK, Friedman JM (2010) Identification of neuronal subpopulations that project from hypothalamus to both liver and adipose tissue polysynaptically. Proc Natl Acad Sci U S A 107:7024-7029. CrossRef Medline

Takase K, Kikuchi K, Tsuneoka Y, Oda S, Kuroda M, Funato H (2014) Meta-analysis of melanin-concentrating hormone signaling-deficient mice on behavioral and metabolic phenotypes. PLoS One 9:e99961. CrossRef Medline

Tecuapetla F, Patel JC, Xenias H, English D, Tadros I, Shah F, Berlin J, Deisseroth K, Rice ME, Tepper JM, Koos T (2010) Glutamatergic signaling by mesolimbic dopamine neurons in the nucleus accumbens. J Neurosci 30:7105-7110. CrossRef Medline

Tecuapetla F, Matias S, Dugue GP, Mainen ZF, Costa RM (2014) Balanced activity in basal ganglia projection pathways is critical for contraversive movements. Nat Commun 5:4315. CrossRef Medline

Tritsch NX, Ding JB, Sabatini BL (2012) Dopaminergic neurons inhibit striatal output through non-canonical release of GABA. Nature 490:262-266. CrossRef Medline

Tritsch NX, Oh WJ, Gu C, Sabatini BL (2014) Midbrain dopamine neurons sustain inhibitory transmission using plasma membrane uptake of GABA, not synthesis. Elife 3:e01936. CrossRef Medline

Trivedi P, Yu H, MacNeil DJ, Van der Ploeg LH, Guan XM (1998) Distribution of orexin receptor mRNA in the rat brain. FEBS Lett 438:71-75. CrossRef Medline

Tsunematsu T, Ueno T, Tabuchi S, Inutsuka A, Tanaka KF, Hasuwa H, Kilduff TS, Terao A, Yamanaka A (2014) Optogenetic manipulation of activity and temporally controlled cell-specific ablation reveal a role for $\mathrm{MCH}$ neurons in sleep/wake regulation. J Neurosci 34:6896-6909. CrossRef Medline

Uschakov A, Grivel J, Cvetkovic-Lopes V, Bayer L, Bernheim L, Jones BE, Mühlethaler M, Serafin M (2011) Sleep-deprivation regulates alpha-2 adrenergic responses of rat hypocretin/orexin neurons. PLoS One 6:e16672. CrossRef Medline

van den Pol AN, Acuna-Goycolea C, Clark KR, Ghosh PK (2004) Physiological properties of hypothalamic MCH neurons identified with selective expression of reporter gene after recombinant virus infection. Neuron 42:635-652. CrossRef Medline 